\title{
Efek terapi oksigen hiperbarik terhadap nilai Montreal Cognitive Assesment Indonesia (MoCA-INA) pada pasien cedera otak traumatik ringan
}

\author{
Leonardo V. Sagay, ${ }^{1}$ Maximilian Ch. Oley, ${ }^{2}$ Mendy J. Hatibie, ${ }^{3}$ Eko Prasetyo, ${ }^{2}$ Fima L. F. \\ G. Langi ${ }^{4}$
}

${ }^{1}$ Program Pendidikan Dokter Spesialis Bagian Ilmu Bedah Fakultas Kedokteran Universitas Sam Ratulangi, Manado, Indonesia

${ }^{2}$ Divisi Bedah Onkologi Bagian Ilmu Bedah Fakultas Kedokteran Universitas Sam Ratulangi/ RSUP Prof. Dr. R. D. Kandou, Manado, Indonesia

${ }^{3}$ Divisi Bedah Plastik Bagian Ilmu Bedah Fakultas Kedokteran Universitas Sam Ratulangi/ RSUP Prof. Dr. R. D. Kandou, Manado, Indonesia

${ }^{4}$ Fakultas Kesehatan Masyarakat, Epidemiologi dan Biostatistik Universitas Sam Ratulangi, Manado, Indonesia

Email: 16015103013@student.unsrat.ac.id

\begin{abstract}
Hyperbaric oxygen therapy (HBOT) uses 100\% oxygen at a pressure of more than 1 ATM in a chamber, therefore, it can improve the state of tissue hypoxia. This study was aimed to prove that TOHB could increase the MoCA-INA score in mild traumatic brain injury (mTBI). This study was carried out at the Surgery Department of Prof. Dr. R. D. Kandou Hospital, Manado using the pre and post trial design. Subjects were 20 patients with mTBI divided into two groups: treated with HBOT and control group (without HBOT). Each patient involved would be examined for MoCA-INA before and after treatment or with HBOT added. The results showed that before treatment, the MoCA-INA scores tended to be evenly distributed around 36 (SD 5). The score increased to 71 (SD 10) at postinjury management or a mean increase of 35 points $(\mathrm{p}<0.001$ in the paired two-sample t-test). However, there was no significat difference in MoCA-INA scores between the first and the second measurements. The density of the two groups clearly overlapped even though the variation of MoCA-INA scores of the HBOT group was much wider than that of the control group ( $\mathrm{p}=0.302$ and 0.297 in the first and second measurements, respectively). There was no cognitive disturbance either mild, moderate, or severe in all patients. In conclusion, there was an increase of the MoCA-INA value in mTBI patients after treatment. The patients treated with HBOT showed wider variation of MoCA-INA score of pre and post HBOT than those without HBOT
\end{abstract}

Keywords: HBOT; mTBI; MoCA-INA; cognitive function

\begin{abstract}
Abstrak: Terapi oksigen hiperbarik (TOHB) menggunakan oksigen 100\% pada tekanan lebih dari 1 ATM dalam sebuah chamber sehingga dapat memperbaiki keadaan hipoksia jaringan. Penelitian ini bertujuan untuk membuktikan bahwa TOHB dapat meningkatkan nilai MoCA-INA pada pasien cedera otak traumatik ringan (COTr). Penelitian dilaksanakan di Bagian Bedah RSUP Prof. Dr. R. D. Kandou, Manado dengan menggunakan pre and posttrial design. Subyek penelitian ialah 20 pasien COTr dibagi dalam dua kelompok: dengan dan tanpa TOHB (kelompok kontrol). Setiap subyek diperiksa MoCAINA sebelum dan sesudah penatalaksanaan cedera/disertai TOHB. Sebelum penatalaksanaan cedera, rerata skor MoCA-INA sekitar 36 (SD 5) dan nilai tersebut meningkat menjadi 71 (SD 10) pasca penatalaksanaan cedera atau kenaikan rerata 35 poin ( $\mathrm{p}<0,001$ pada uji t dua sampel berpasangan). Tidak tampak perbedaan skor MoCA-INA baik pada pengukuran pertama maupun kedua. Densitas kedua kelompok terlihat jelas tumpang tindih sekalipun variasi skor MoCA-INA group TOHB jauh lebih lebar daripada group kontrol ( $\mathrm{p}=0,302$ dan 0,297 masing-masing pada pengukuran pertama dan kedua). Tidak terlihat adanya gangguan kognitif ringan sedang maupun berat pada semua pasien. Simpulan penelitian ini ialah terdapat peningkatan nilai MoCA-INA pada pasien COTr. Pasien dengan TOHB memperlihatkan variasi skor MoCA-INA yang lebih besar pada pre dan pasca TOHB.
\end{abstract}

Kata kunci: TOHB; COT; MoCA-INA; gangguan kognitif 


\section{PENDAHULUAN}

Cedera otak traumatik ringan (COTr) adalah cedera otak akut akibat energi mekanik ke kepala dari kekuatan fisik eksternal. Kriteria operasional untuk identifikasi klinis meliputi: 1) Satu atau lebih dari berikut ini: kebingungan atau disorientasi, kehilangan kesadaran selama 30 menit atau kurang, amnesia pasca trauma kurang dari 24 jam, dan/atau kelainan neurologik sementara lainnya seperti tanda fokal, kejang, dan lesi intrakranial yang tidak memerlukan pembedahan; 2) Skor GCS 13-15 setelah 30 menit pasca-cedera atau lebih setelah presentasi untuk perawatan kesehatan; 3) Manifestasi COTr tidak boleh disebabkan oleh obatobatan, alkohol, obat-obatan yang disebabkan oleh cedera lain atau perawatan untuk cedera lain (misalnya, cedera sistemik, cedera wajah, atau intubasi), yang disebabkan oleh masalah lain (misalnya, trauma psikologis, halangan bahasa, atau kondisi medis yang terdapat bersamaan), atau disebabkan oleh cedera tembus kraniocerebral. ${ }^{1}$ Data terkini dari Global Neurosurgery Initiative menyebutkan bahwa traumatic brain injury sebagai "silent epidemic" yang menyebabkan angka kematian dan kecatatan lebih tinggi dari jenis taruma lainnya, dan diperkirakan sebanyak 69 juta kasus pertahun di seluruh dunia dan terbesar di Asia dan Afrika disebabkan oleh kecelakaan lalu lintas. ${ }^{2}$ Data dari Indonesia di Rumah Sakit Sanglah Denpasar Bali mendapatkan sekitar 2000 kasus dengan proporsi cedera kepala ringan mencapai $80 \%$ dari semua kasus cedera kepala. ${ }^{3,4}$ Diperkirakan angka masuk rumah sakit terkait COT sebesar 224.000 di tahun 2017 berdasarkan laporan surveilans CDC dengan proporsi terbesar pada orang tua lebih dari 75 tahun. Penyebab tersering ialah karena jatuh dan kecelakaan motor. ${ }^{5}$ Berdasarkan hasil Riskesdas Provinsi Sulawesi Utara menduduki urutan ke tiga setelah Gorontalo (Pertama) dan Papua (kedua), dimana proporsi cedera akibat lalu lintas menduduki urutan pertama. ${ }^{6}$

Gejala pasca gegar otak biasanya dilaporkan setelah cedera otak traumatis ringan (COTr), dan yang paling umum ialah sakit kepala, penglihatan kabur, pusing, masalah tidur dan suasana hati, serta masalah memori subjektif dan gangguan kognitif lainnya. ${ }^{7}$ Mengenai gangguan kognitif pasca COTr, sebuah metaanalisis mengungkapkan bahwa fungsi eksekutif, ingatan tertunda, kelancaran verbal dan fungsi visuospasial merupakan fungsi kognitif yang paling rentan dipengaruhi oleh COTr. ${ }^{8}$ Ganguan kognitif ini akan menggangu kualitas hidup pasien pasca COTr, dalam hal pekerjaan, aktivitas sehari-hari, hubungan, citra sosial, dan selanjutnya akan membebani ekonomi masyarakat dan bangsa. ${ }^{9}$ Dampak pada kognisi karena TBI telah mendapat perhatian besar di seluruh dunia dalam dua dekade terakhir dan telah menjadi topik yang menarik bagi para peneliti. Salah satu alat yang dipakai untuk menilai gangguan kognitif pada pasien cedera kepala ialah Montreal cognitive assesment (MoCA) karena dapat menilai ganguan kognitif pada COTr dengan sentitivitas tinggi. ${ }^{7,10}$

Terapi oksigen hiperbarik (TOHB) adalah modalitas terapi dengan memberikan inhalasi oksigen $100 \%$ dalam sebuah chamber dengan tekanan lebih dari 1 atmosfer (ATM), biasanya diberikan dalam tekanan 1-3 ATM. ${ }^{11}$ TOHB telah lama dikembangkan dalam dunia kedokteran, yaitu sejak abad ke 17 saat Henshaw merancang chamber hiperbarik dan kemudian Boerema melaporkan TOHB sebagai terapi untuk bedah kardiopulmonar. ${ }^{12}$ TOHB dapat memperbaiki fungsi kognitif penderita COTr. ${ }^{13}$ Marcinkowska et $\mathrm{al}^{11}$ dalam sebuah systematic review mnenyebutkan bahwa TOHB membutuhkan penelitian lebih lanjut, tetapi Hadanny et ${ }^{14}$ al dalam sebuah studi retrospektif menyebutan bahwa TOHB dikaitkan dengan perubahan kognitif yang bermakna. Pada sebuah laporan kasus oleh Skiba et al ${ }^{12}$ mengenai pasien cedera kepala berat dengan frontal lobe syndrome dimana pengaruh TOHB diikuti sampai lima bulan dan diberikan 42 seri TOHB 3 kali seminggu kemudian ditingkatkan sampai lima kali seminggu pada masa rehabilitasi dan didapatkan fungsi kognitf meningkat, kerapuhan emosi menghilang, dan kemampuan memori jangka pendek meningkat. Berdasarkan latar belakang yang telah dipaparkan penulis terdorong untuk meneliti apakah TOHB dapat meningkatkan nilai MoCA-INA. 


\section{METODE PENELITIAN}

Penelitian ini dilaksanakan di Bagian Bedah RSUP Prof. Dr. R. D. Kandou Manado sejak bulan Juli hingga Oktober 2020 dengan menggunakan pre and posttrial design. Subjek penelitian ialah 20 orang pasien COTr yang masuk dalam kriteria inklusi dengan onset trauma saat masuk ke IRDB RSUP Prof. Dr. R. D. Kandou dan kontrol rawat jalan di Poliklinik RSUP Prof. Dr. R. D. Kandou, usia 16-45 tahun, memenuhi kriteria diagnosis cedera otak traumatik oleh sebab apapun, nilai Glasgow coma scale (GCS) 14-15, memberikan persetujuan tertulis untuk berpartisipasi dalam penelitian melalui lembar informed consent. Pasien yang memenuhi persyaratan inklusi kemudian dieksklusi dari daftar bakal sampel saat diketahui pasien tersebut: a) Memiliki riwayat cedera kepala akibat trauma sebelumnya; b) Telah atau akan menjalani operasi; c) Mengidap penyakit infeksi/sistemik yang dapat mengganggu proses inflamasi; d) Memiliki riwayat konsumsi obatobatan atau zat yang dapat memengaruhi kesadaran atau inflamasi; (e) Mengalami multiple injury selain cedera kepala; f) Memiliki cedera penyerta seperti crush injury, fraktur tulang panjang, trauma tumpul atau tajam pada toraks atau abdomen; g) Pada pemeriksaan lanjut didapatkan tanda dan gejala proses inflamasi sebelumnya; h) Menolak atau tidak dapat menjalani $C T$ scan dan pemeriksaan MoCA-INA; dan i) Memiliki kontraindikasi terhadap TOHB.

Pengumpulan data mencakup diagnosis fisik dan pemeriksaan klinis, fasilitas radiologik khususnya $C T$ scan. Pasien diperiksa MoCA-INA saat masuk rumah sakit dan kemudian saat satu bulan setelah TOHB.

Pembuktian pengaruh TOHB terhadap MoCA-INA dalam penelitian ini menerapkan desain controlled trial. Subjek penelitian dialokasikan ke dalam salah satu dari dua kelompok perlakuan: pasien yang menerima TOHB dan pasien kontrol. Alokasi tersebut tidak berlangsung random (quasi experimental), melainkan menurut tempat di mana pasien di rawat. Pasien di rumah sakit penelitian dengan fasilitas oksigen hiperbarik dirawat sebagai kelompok TOHB bila memenuhi kriteria dan setuju berpartisipasi dalam studi, sedangkan pasien di rumah sakit tanpa fasilitas TOHB dirawat sebagai kelompok kontrol dengan terapi konvensional COT ringan. Pasien kelompok TOHB mendapatkan sesi terapi oksigen $100 \%$ dalam ruangan bertekanan 2,4 ATA selama 60 menit, sebagai tambahan atas terapi konvensional COT ringan yang juga diterima. Pemeriksaan MoCAINA pada kedua kelompok dilakukan dua kali. Pemeriksaan pertama dilakukan pada pemeriksaan saat pasien berkunjung pertama kali di IGD sedangkan pemeriksaan kedua saat kontrol di rawat jalan dalam kurun waktu satu bulan setelah perawatan konvensional COTr dimulai pada kelompok kontrol, atau sesudah pemberian oksigen hiperbarik selesai untuk kelompok TOHB.

Analisis univariat mencakup penilaian distribusi setiap variabel, termasuk normalitas variabel numerik. Evaluasi ini dilakukan menggunakan grafik seperti histogram, boxplot, dan kurva densitas, di samping uji normalitas Shapiro-Wilk. Pada variabel kategori, penilaian distribusi dilakukan melalui tabel frekuensi. Nilai pemusatan dan penyebaran dihitung menurut jenis variabel dan normalitas distribusi untuk yang numerik. Hasil uji normalitas kemudian mensyaratkan penyajian seluruh variabel numerik dalam bentuk median dan rentang antar kuartil (interquartile range, IQR).

Penelitian ini telah mendapat persetujuan dari Komisi Etik Penelitian Kesehatan RSUP Prof. Dr. R. D. Kandou Manado, dengan nomor keterangan layak etik yaitu No. 047/EC/KEPK-KANDOU/VI/2020.

\section{HASIL PENELITIAN}

Tabel 1 memperlihatkan karakteristik pasien cedera otak traumatik ringan dalam penelitian ini $(\mathrm{N}=20)$. Jenis kelamin laki-laki jauh lebih banyak daripada perempuan (18 vs 2) dengan median usia sebesar 24.0.

Gambar 1 menampilkan secara visual perubahan skor MoCA-INA pada dua waktu pengukuran, yakni sebelum dan 1-3 minggu setelah penatalaksanaan cedera sedangkan pada group TOHB, segera setelah pemberian TOHB. Tampak jelas bahwa umumnya skor MoCA-INA meningkat di pengukuran kedua. 
Tabel 1. Karakteristik pasien cedera otak traumatik ringan $(\mathrm{N}=20)$

\begin{tabular}{|c|c|c|c|}
\hline Katakteristik & Mean \pm SD & Median $\left(Q_{1}-Q_{3}\right)$ & $n(\%)$ \\
\hline \multicolumn{4}{|l|}{ Kelamin } \\
\hline Laki-laki & - & - & $18(90)$ \\
\hline Perempuan & - & - & $2(10)$ \\
\hline Usia & - & $24,0(22,0-48,8)$ & - \\
\hline Dengan ICH & - & - & $10(50)$ \\
\hline Hemoglobin (g/dL) & $14,1 \pm 2,4$ & - & - \\
\hline Eritrosit $\left(\right.$ x $\left.10^{6} / \mu \mathrm{L}\right)$ & $4,8 \pm 0,8$ & - & - \\
\hline Leukosit (x $\left.10^{3} / \mu \mathrm{L}\right)$ & - & $14,9(7,3-39,5)$ & - \\
\hline Trombosit $\left(\mathrm{x} 10^{3} / \mu \mathrm{L}\right)$ & $244,4 \pm 90,2$ & - & - \\
\hline Hematokrit (\%) & $40,9 \pm 7,4$ & - & - \\
\hline PT (s) & - & $11,2(9,7-13,4)$ & - \\
\hline $\operatorname{APTT}(\mathrm{s})$ & $30,5 \pm 4,8$ & - & - \\
\hline INR & $1,0 \pm 0,2$ & - & - \\
\hline SGOT (mg/dL) & - & $31,0(21,5-42,5)$ & - \\
\hline SGPT (mg/dL) & - & $28,0(16,5-34,0)$ & - \\
\hline Ureum (mg/dL) & - & $25,0(19,0-28,6)$ & - \\
\hline Kreatinin (mg/dL) & - & $0,8(0,7-0,9$ & - \\
\hline Natrium (mEq/L) & $138,4 \pm 3,3$ & - & - \\
\hline Kalium (mEq/L) & $4,1 \pm 0,3$ & - & - \\
\hline Klorida $(\mathrm{mEq} / \mathrm{L})$ & $100,4 \pm 3,4$ & - & - \\
\hline
\end{tabular}

Ket: SD, standar deviasi; Q1, kuartil I; Q3, kuartil III; PT, prothrombin time; APTT, activated partial thromboplastin time; INR, international normalized ratio; SGOT, serum glutamic oxaloacetic transaminase; SGPT, serum glutamatepyruvate transaminase; ICH, intracranial hemorrhage; HIF-1, hypoxia inducible factor-1; TOHB, terapi oksigen hiperbarik

Sebelum penatalaksanaan cedera, rerata skor MoCA-INA sekitar 36 dengan deviasi sebesar 5 skor. Nilai tersebut meningkat menjadi 71 (SD 10) pasca penatalaksanaan cedera atau kenaikan rerata 35 poin $(\mathrm{p}<0,001$ pada uji t dua sampel berpasangan).

Tidak tampak perbedaan skor MoCAINA baik pada pengukuran pertama (Gambar 2) maupun kedua (Gambar 3). Densitas kedua kelompok terlihat jelas tumpang tindih sekalipun variasi skor MoCA-INA group TOHB jauh lebih lebar daripada group kontrol ( $\mathrm{p}=0,302$ dan 0,297 masing-masing pada pengukuran pertama dan kedua).

Analisis pengaruh TOHB terhadap perubahan skor MoCA tidak memberikan hasil yang bermakna. Model regresi linear yang dikembangkan gagal menunjukkan peran group variabel (koefisien regresi 2,4; $\mathrm{p}=0,289$ ). Gambar 4 memberikan konfirmasi visual akan hal tersebut. Grafik boxplot mem- perlihatkan bahwa sekalipun terdapat kesenjangan lebar antara skor MoCA-INA di kedua waktu pengukuran, distribusi kedua group penelitian justru tidak jauh berbeda.

\section{BAHASAN}

Penghantaran oksigen dalam darah pada keadaan normal tergantung pada afinitas oksigen dengan hemoglobin, dan sebagian kecil terdapat dalam plasma. Kadar hemoglobin sangat berpengaruh dalam antaran oksigen. Selain itu, status hemodinamik juga sangat berpengaruh dalam antaran oksigen. Berkaitan dengan itu, pada keadaan COTr status hemodinamik dapat saja terganggu, mekanisme autoregulasi akan bekerja untuk tetap memberikan antaran oksigen dan perfusi ke dalam sel otak. Aliran darah serebral (ADS) juga memainkan peran berbeda dalam menjaga pasokan oksigen otak. Sistem autoregulasi otak bertujuan untuk menjaga ADS 


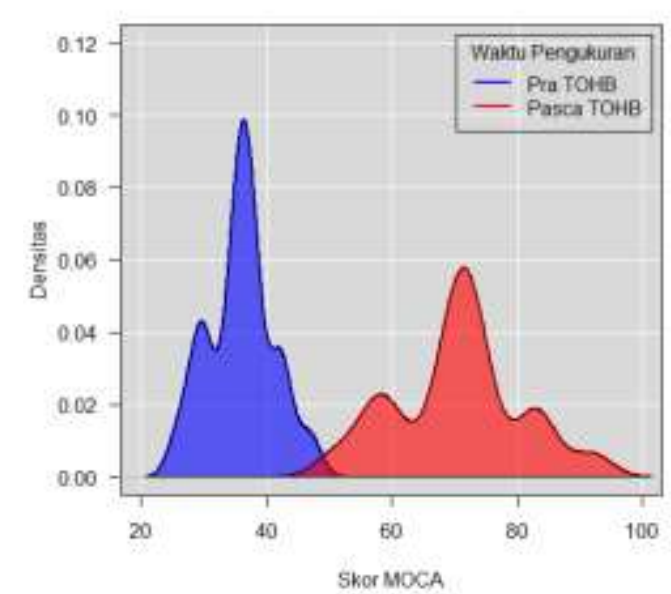

Gambar 1. Distribusi skor MoCA-INA sebelum dan sesudah TOHB

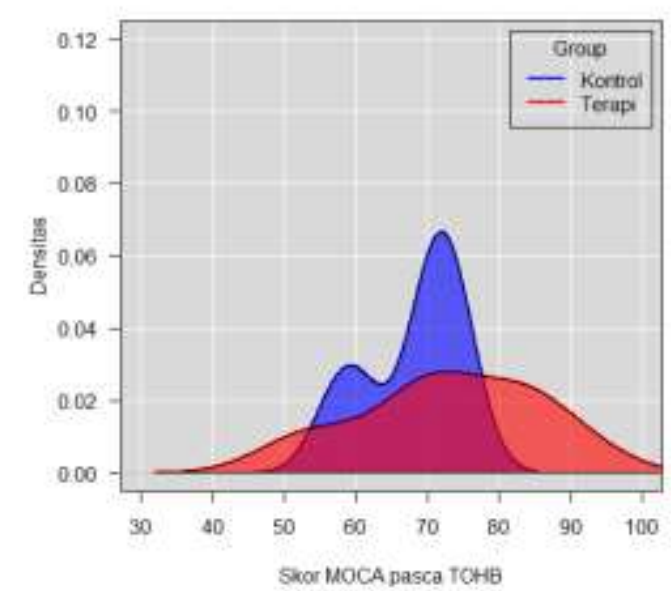

Gambar 3. Densitas skor MOCA pada pengukuran lanjutan sesudah terapi

global konstan, mengingat tekanan darah arteri rerata berada dalam kisaran fisiologis $50-150 \mathrm{~mm} \mathrm{Hg}{ }^{15}$

Dalam sistem autoregulasi yang utuh, ADS lokal juga disesuaikan untuk memenuhi permintaan area yang berbeda, atau untuk mengurangi kelebihan pengiriman oksigen. Terjadiya hipoksia sesaat atau berlangsung lama dalam sel otak merupakan jantung walaupun hanya sekitar $2 \%$ dari berat tubuh ${ }^{15}$ Keadaan ini membuat otak sangat rentan akan kekurangan oksigen dan sensitif dengan keadaan hipoksia. Terapi yang meningkatkan

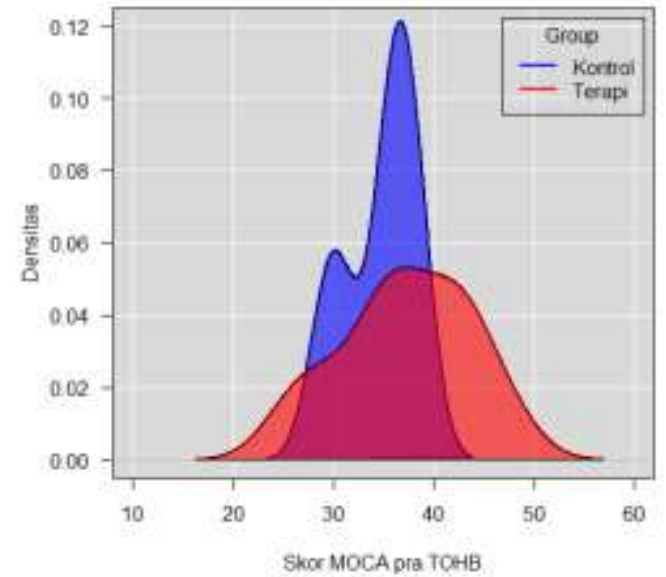

Gambar 2. Densitas skor MoCA-INA sebelum terapi menurut kelompok

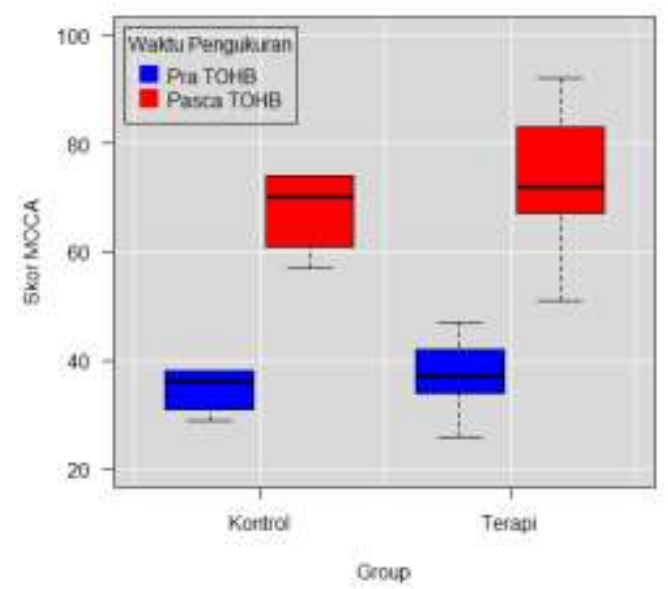

Gambar 4. Perbandingan distribusi skor MoCAINA pada kedua kelompok penelitian sebelum dan sesudah terapi

FiO2 pada udara inspirasi terbukti meningkatkan oksigenasi arteri dan sel otak. ${ }^{16}$

Mekanisme kerusakan sel otak melibatkan banyak jalur. Prasetyo ${ }^{17}$ menyebutkan terdapat tiga tahap dan proses cedera otak. Primer, yang disebabkan pada saat terjadinya cedera, dapat dicegah tetapi tidak bisa diobati. Pada saat terjadinya benturan terjadi contusio, robekan dan diffuse axonal injury sebagai akibat shearing, tearing, atau stretching. Sekunder, merupakan lanjutan dari cedera primer. Proses yang terjadi disini disebabkan oleh proses iskemia, peradangan, dan sitotoksik. 
Tersier, proses yang disebabkan oleh peradangan persisten dan perubahan epigenetik yang menghambat pematangan oligodendrosit, gangguan neurogenesis, gangguan pertumbuhan aksonal, atau gangguan sinaptogenesis. Tahap dan proses ini menjadi kerangka untuk memahami seluruh proses yang terjadi pada cedera otak traumatis. Lebih lanjut lagi, menurut Rana et $\mathrm{al}^{18}$ cedera otak sekunder terjadi karena proses neurokimia (monoamin oxidase/MAO, dopamin, serotonin, norepinefrin), proses metabolik (glikolisis dan metabolisme oksidatif dalam astrosit), dan proses selular (gangguan morfologik mitokondria). Karakter tertunda dari cedera otak sekunder memungkinkan jendela terapi untuk mencegah apoptosis sel saraf yang berujung pada gangguan kognitif dan motorik. Pada keadaan lanjutan COTr akan berhadapan dengan proses apotosis yang dimediasi oleh proses yang melibatkan tumor suppressor P53, caspase -3-.-8.-9, dan Bcl2 protein yang kemudian menyebabkan apoptosis sel. TOHB merupakan terapi yang paling efektif untuk menghantarkan oksigen ke semua sel-sel tubuh, bahkan ke tempat di mana terdapat gangguan pembuluh darah. ${ }^{12} \mathrm{Hal}$ ini dimungkinkan karena saat pemberian TOHB tekanan partial oksigen meningkat oleh kelarutan oksigen dalam plasma meningkat.

Mengenai gangguan kognitif pasca COTr, sebuah metaanalisis ${ }^{19}$ mengungkapkan bahwa fungsi eksekutif, ingatan yang tertunda, kefasihan verbal, dan fungsi visuospasial merupakan fungsi kognitif yang paling rentan dipengaruhi oleh COTr. Dua meta-analisis lainnya juga melaporkan bahwa defisit kognitif yang paling sering dapat diamati antara 48 jam dan 1 bulan setelah kejadian ialah gangguan konsentrasi, penurunan kecepatan pemrosesan informasi, dan kesulitan dalam pembelajaran verbal. Gejala pascagegar otak biasanya dilaporkan setelah cedera otak traumatis ringan (COTr), dan yang paling umum ialah sakit kepala, penglihatan kabur, pusing, masalah tidur dan suasana hati, serta masalah memori subjektif dan gangguan kognitif lainnya. ${ }^{7}$ Menurut Feritas et $\mathrm{al}^{20}$ gangguan kognitif dapat terjadi dalam 24 jam setelah trauma yang disebut fake akut kemudian dapat berkembang menjadi gangguan jangka panjang dan menurunkan kualitas hidup pasien. Lebih rinci lagi Feritas et $\mathrm{al}^{20}$ menyatakan bahwa gangguan yang terjadi berkaitan dengan ganguan ingatan dan eksekutif pasien, dan juga menyebutkan bahwa tidak terdapat perbedaan kognitif pada pasien dengan riwayat kehilangan kesadaran dan tidak dalam 24 jam setelah cedera terjadi. Hal ini yang mendasari penulis untuk melakukan pemeriksaan kognitif saat pasien datang ke intalasi gawat daurat rumah sakit. Untuk proses selanjut terkait menetapnya gangguan kognitif, penelitian yang dilakukan oleh Bedard et $\mathrm{al}^{21}$ dengan mengunakan data Canadian Longitudinal Study on Aging menyebutkan bahwa pasien dengan riwayat COTr sejak 12 bulan lalu dengan riwayat kehilangan kesadaran akan mengalami gangguan eksekutif dan ingatan. McInnes et $\mathrm{al}^{22}$ menyebutkan bahwa gangguan kognitif biasanya hilang dalam tiga bulan setelah cedera tetapi hasil review yang dilakukanya menyatakan bahwa sekitar setengah dari pasien yang mengalami sekali COTr menderita gangguan kognitif jangka panjang.

Peran TOHB dalam COTr terbagi dalam bebebrapa mekanisme. Hu et $\mathrm{al}^{23}$ menjelaskan secara rinci mengenai mekanisme TOHB pada cedera otak. Terdapat banyak jalur yang bekerja paralel atau bersama-sama, untuk menginduksi perlindungan saraf di otak. Mekanisme ini meliputi: 1) meningkatkan oksigenasi jaringan; 2) mengurangi peradangan; 3) menurunkan apoptosis; 4) mengurangi intracranial pressure (ICP); serta 5) memro-mosikan neurogenesis dan angiogenesis. dalam sebuah meta analisis. ${ }^{24}$ Pada sebuah meta analisis, pasien COTr yang menjalani TOHB mencapai Skala Koma Glasgow (SKG) dan Skala Luaran Glagow ( SLG) yang meningkat secara bermakna dengan angka mortalitas yang rendah. Sebagai bukti anatomis, Hadanny et $\mathrm{al}^{14}$ melakukan pemeriksaan single photon emission computed tomography (SPECT) otak pasca perawatan dan mengungkapkan korelasi anatomis-fungsional sehubungan dengan efek TOHB pada neuroplastisitas otak. Hal ini juga selaras dengan hasil penelitian ini yaitu fungsi kognitif lewat penilaian MoCA-INA menunjukkan perbaik- 
an walaupun tidak bermakna secara statistik.

MoCA-INA merupakan salah satu uji yang dipakai dalam penyaringan untuk menilai gangguan kognitif. Uji ini pertama kali dipublikasikan oleh Nasreddine et al $2005^{10}$ yang dikembangkan untuk menilai gangguan kognitif pada pasien Alzheimer. Pada perkembangannya uji ini secara luas dipakai untuk menilai gangguan kognitif pada berbagai kasus termasuk COTr. Ontario Neurotrauma Foundation pada tahun 2018 merekomendasikan MoCA untuk dipakai dalam menilai gangguan kognitif pasien terutama yang persisten. ${ }^{25}$ Penelitian yang dilakukan oleh Franette et $\mathrm{al}^{7}$ menyimpulkan bahwa MoCA secara klinis mungkin bermanfaat untuk skrining kognitif segera setelah COTr karena MoCA menunjukkan sensitivitas tehadap gangguan kognitif pada pasien COTr. Uji ini kemudian divalidasi tahun 2019 oleh Tay et $\mathrm{al}^{26}$ pada pasien COT sedang dan berat namun hasil uji ini kurang sensitif. Validasi MoCA telah dilakukan dalam bahasa Prancis pada tahun $2016^{27}$ dan dalam bahasa Indonesia oleh Husien et $\mathrm{al}^{28}$ tahun 2010 di Universitas Indonesia dan Rumah Sakit Cipto Mangunkusumo. Validitas lainya telah dipakai pada pasien paska stroke di Palembang pada tahun 2013. ${ }^{29}$ Untuk selanjutnya uji ini lebih dikenal di Indonesia sebagai MoCA-INA yang memiliki tingkat sensitivitas dan spesifitas yang tinggi, serta dapat dipercaya dalam pengunaannya. 10,25,28,29 Adanya MoCA-INA akan mengurangi bias yang disebabkan oleh kendala bahasa. Dengan demikian penulis memiliki dasar kuat dalam penggunaan MoCA-INA dalam penelitian ini yang mendukung didapatkannya hasil dengan akurasi yang tinggi.

Hasil analisis data penelitian ini memperlihatkan perbaikan nilai MoCAINA setelah TOHB walaupun tidak bermakna secara statistik. Hal ini selaras dengan penelitian yang dilakukan oleh Liu et $\mathrm{al}^{13}$ yang menunjukkan bahwa terjadi perbaikan kognitif setelah TOHB. Penelitian di India oleh Panwar et $\mathrm{al}^{9}$ pada pasien COTr dengan mengunakan MoCA menyatakan bahwa gangguan visuospatial, ingatan, dan perhatian merupakan fungsi kognitif yang terganggu. Hal ini sejalan dengan temuan yang didapatkan dalam penelitian ini, terutama pada saat sebelum TOHB.

\section{SIMPULAN}

Pada pasien COTr yang mendapatkan TOHB terjadi peningkatan fungsi kognitif melalui pemeriksan MoCA-INA walaupun tidak bermakna secara statistik. Disarankan untuk melakukan penelitian dengan jumlah sampel lebih besar dan uji validitas untuk pemeriksaan fungsi kognitif pasien $\mathrm{COTr}$ menggunakan MoCA-INA dengan harapan pemeriksaan MoCA-INA dapat menjadi pemeriksaan rutin pada setiap kasus COTr.

\section{Konflik Kepentingan}

Penulis menyatakan tidak terdapat konflik kepentingan dalam studi ini.

\section{DAFTAR PUSTAKA}

1. Kristman VL, Borg J, Godbolt AK, Salmi LR, Cancelliere C, Carroll LJ, et al. Methodological issues and research recommendations for prognosis after mild traumatic brain injury: Results of the international collaboration on mild traumatic brain injury prognosis. Arch Phys Med Rehabil. 2014;95(Suppl3): S265-77.

Doi:10.1016/j.apmr.2013.04.026

2. Dewan MC, Rattani A, Gupta S, Baticulon RE, Ya $\mathrm{CH}$, Punchak M, et al. Estimating the global incidence of traumatic brain injury. J Neurosurg. 2019;130(4):108097. Doi:10.3171/2017.10.JNS17352

3. Yasa IMWDP, Golden N, Niryana IW. Faktorfaktor yang berhubungan dengan tindakan operasi pada pasien cedera kepala ringan dan cedera kepala sedang di RSUP Sanglah Denpasar periode Januari-Desember 2017. Medicina. 2019;50(1):174-9.

Doi:10.15562/medicina.v50i1.471

4. Faul M, Coronado V. Epidemiology of traumatic brain injury. In: Handbook of Clinical Neurology Vol 127. Elsevier B.V, 2015; p. 3-13. Doi:10.1016/B9780-444-52892-6.00001-5

5. Surveillance report of traumatic brain injuryrelated emergency department visits, hospitalizations, and deaths United States. 2014. Available from: https: //www.cdc.gov/traumaticbraininjury/ 
pdf/TBI-Surveillance-Report-FINAL_ 508.pdf

6. Hasil Utama Riskerdas. [cited 2021 Sep 16]. Available from: https://www.litbang. kemkes.go.id/laporan-riset-kesehatandasar-riskesdas/

7. Frenette LC, Tinawi S, Correa JA, Alturki AJ, LeBlanc J, Feyz M, et al. Early detection of cognitive impairments with the Montreal Cognitive Assessment in patients with uncomplicated and complicated mild traumatic brain injury. Brain Inj. 2018;1(2).

Doi:10.1080/02699052.2018.1542506

8. Karr JE, Areshenkoff CN, Garcia-Barrera MA. The neuropsychological outcomes of concussion: a systematic review of meta-analyses on the cognitive sequelae of mild traumatic brain injury. Neuropsychology. 2014;28(3):321-6. Doi: $10.1037 /$ neu0000037

9. Panwar N, Purohit D, Deo Sinha V, Joshi M. Evaluation of extent and pattern of neurocognitive functions in mild and moderate traumatic brain injury patients by using Montreal Cognitive Assessment (MoCA) score as a screening tool: an observational study from India. Asian J Psychiatr. 2019;41:60-65.

Doi:10.1016/j.ajp.2018.08.007

10. Nasreddine ZS, Phillips NA, Bédirian V, Charbonneau S, Whitehead V, Collin I, et al. The Montreal Cognitive Assessment, MoCA: a brief screening tool for mild cognitive impairment. J Am Geriatr Soc. 2005;53(4):695-99.

Doi:10.1111/j.1532-5415.2005.53221.x

11. Marcinkowska AB, Mankowska ND, Kot J, Winklewski PJ. Impact of hyperbaric oxygen therapy on cognitive functions: a systematic review. Neuropsychol Rev. Published online 2021.

Doi:10.1007/s11065-021-09500-9

12. Skiba M, Rękas-Dudziak A, Bekała A, Płotek W. Late application of hyperbaric oxygen therapy during the rehabilitation of a patient with severe cognitive impairment after a traumatic brain injury. Clin Case Rep. 2021;9(2). Doi:10.1002/ccr3.3658

13. Liu S, Shen GY, Deng SK, Wang X bin, Wu QF, Guo AS. Hyperbaric oxygen therapy improves cognitive functioning after brain injury. Neural Regen Res. 2013; 8(35):3334-43. Doi:10.3969/j.issn.
1673-5374.2013.35.008

14. Hadanny A, Abbott S, Suzin G, Bechor Y, Efrati S. Effect of hyperbaric oxygen therapy on chronic neurocognitive deficits of post-traumatic brain injury patients: retrospective analysis. BMJ Open. 2018;8(9). doi:10.1136/bmjopen2018-023387

15. Beynon C, Kiening KL, Orakcioglu B, Unterberg AW, Sakowitz OW. Brain tissue oxygen monitoring and hyperoxic treatment in patients with traumatic brain injury. J Neurotrauma. 2012;29 (12):2109-23.

Doi:10.1089/neu.2012.2365

16. Wettervik TMS, Lewén A, Enblad P. Fine tuning of traumatic brain injury management in neurointensive care - indicative observations and future perspectives. Front Neurol. 2021;12.

Doi:10.3389/fneur.2021.638132

17. Prasetyo E. The primary, secondary, and tertiary brain injury. Crit Care Shock. 2020; 23:4-13.

18. Rana A, Singh S, Sharma R, Kumar A. Traumatic brain injury altered normal brain signaling pathways: implications for novel therapeutics approaches. Curr Neuropharmacol. 2018;17(7):614-29. Doi:10.2174/1570159x1666618091112 1847

19. Karr JE, Areshenkoff CN, Garcia-Barrera MA. The neuropsychological outcomes of concussion: A systematic review of meta-analyses on the cognitive sequelae of mild traumatic brain injury. Neuropsychology. 2014;28(3). Doi:10.1037/neu0000037

20. de Freitas Cardoso MG, Faleiro RM, de Paula JJ, et al. Cognitive impairment following acute mild traumatic brain injury. Frontiers in Neurology. 2019;10:198.. Doi:10.3389/fneur.2019.00198

21. Bedard M, Steffener J, Taler V. Long-term cognitive impairment following single mild traumatic brain injury with loss of consciousness: Findings from the Canadian Longitudinal Study on Aging. J Clin Exp Neuropsychol. 2020;42(4): 344-51.

Doi:10.1080/13803395.2020.1714552

22. McInnes K, Friesen CL, MacKenzie DE, Westwood DA, Boe SG. Mild traumatic brain injury (mTBI) and chronic cognitive impairment: a scoping review. 
PLoS ONE. 2017;12(4).

Doi:10.1371/journal.pone.0174847

23. Hu Q, Manaenko A, Xu T, Guo Z, Tang J, Zhang J. Hyperbaric oxygen therapy for traumatic brain injury: Bench-to-bedside. Med Gas Res. 2016; 6(2):102-10. Doi:10.4103/2045-9912.184720

24. Wang F, Wang Y, Sun T, Yu H lin. Hyperbaric oxygen therapy for the treatment of traumatic brain injury: a meta-analysis. Neurological Sciences. 2016;37(5):693701. Doi:10.1007/s 10072-015-2460-2

25. Ontario Neurotrauma Foundation. Guideline for concussion/mild traumatic brain injury \& persistent symptoms healthcare professional version adults (18+ years of age) Guideline for Concussion/Mild Traumatic Brain Injury \& Prolonged Symptoms. 2018. [cited 2021 Sept 17]. Available from: https://braininjury guidelines.org/concussion/fileadmin/pd f/Concussion_guideline_3rd_edition_fi nal.pdf

26. Tay MRJ, Soh YM, Plunkett TK, Ong PL,
Huang W, Kong KH. The validity of the Montreal Cognitive Assessment for moderate to severe traumatic brain injury patients. Am J Phys Med Rehabil. 2019;98(11):971-5.

Doi:10.1097/PHM.0000000000001227

27. Nasreddine ZS, Patel BB. Validation of Montreal Cognitive Assessment, MoCA, alternate French versions. Canad J Neurol Sci. 2016;43(5):665-71. Doi:10.1017/cjn.2016.273

28. Husein N, Lumempouw S, Ramli Y, Herqutanto. Uji validitas dan reliabilitas Montreal cognitive assessment versi Indonesia (MoCA-Ina) untuk skrining gangguan fungsi kognitif. Neurona. 2010;27(4).

29. Panentu D, Irfan M. Uji validitas dan reliabilitas butir pemeriksaan dengan Montreal Cognitive Assesment versi Indonesia (MOCA-INA) pada insan pasca stroke fase recovery. Jurnal Fisioterapi. 2013;13(1);55-67. 